\title{
Ammonoid taphonomy, palaeoenvironments and sequence stratigraphy at the Bajocian/Bathonian boundary on the Bas Auran area (Subalpine Basin, south-eastern France)
}

\author{
SIXTO R. FERNÁNDEZ-LÓPEZ
}

LETHAIA

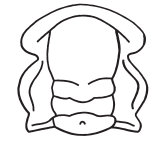

Fernández-López, S.R. 2007: Ammonoid taphonomy, palaeoenvironments and sequence stratigraphy at the Bajocian/Bathonian boundary on the Bas Auran area (Subalpine Basin, south-eastern France). Lethaia, Vol. 40, pp. 377-391.

Bas Auran, in south-eastern France, is the candidate area for Global Boundary Stratotype Section and Point (GSSP) of the base of the Bathonian Stage (Middle Jurassic). In the Bas Auran area, upper Bajocian and lower Bathonian deposits are made up of limestone beds alternating with marls that correspond to the 'Marno-calcaires à Cancellophycus', below the 'Terres Noires' Formation. Taphonomic analyses of the successive ammonoid fossil assemblages provide new and complementary data for biostratigraphic completeness, palaeoenvironmental setting and sequence stratigraphy. Lithologic differentiation between limestone and marl intervals resulted from alternating episodes of carbonate input and starvation. Both lithologic phases may contain evidence for sedimentary and taphonomic reworking, associated with scours, that reflects low rates of sedimentation and stratigraphic condensation. Three successive types of elementary cycles resulted from increasing rates of stratigraphic condensation, sedimentary condensation and substrate stabilization during early Bathonian. The occurrence of reelaborated ammonoids (i.e. exhumed and displaced before their final burial) implies that tractive current flows or winnowing affected the burial of concretionary internal moulds. In the lower Bathonian strata, the dominance of homogeneous concretionary internal moulds of phragmocones, completely filled with sediment, is indicative of low rates of sedimentation and sediment accumulation, respectively associated with low degrees of stratigraphic and sedimentary condensation. However, at the Bajocian/ Bathonian transition, hemipelagic, bed-scale limestone-marl alternations show a maximum value of biostratigraphic completeness and there is no evidence for taphonomic condensation in the ammonoid fossil assemblages. Taphonomic analyses of the successive ammonoid fossil assemblages and taphofacies confirm the development of a deepening phase associated with sedimentary starvation, which characterizes the last episode within the deepening half-cycle of third and second order cycles, in the Bas Auran area of French Subalpine Basin during early Bathonian. $\square$ Bathonian GSSP, condensation, fossilization, limestone-marl cycles, Middle Jurassic.

Sixto R. Fernández-López [sixto@geo.ucm.es], Departamento y UEI de Paleontología, Facultad de Ciencias Geológicas (UCM) e Instituto de Geología Económica (CSIC-UCM), 28040-Madrid, Spain; manuscript received on 10/01/2007; manuscript accepted on $10 / 06 / 2007$.
The candidate section of the base of Bathonian Stage is located in the Bès ravine, at Bas Auran area, near Chaudon-Norante, in the Geological Reserve of Haute-Provence (department 04), around $4 \mathrm{~km}$ west of Barrême and $25 \mathrm{~km}$ southeast of Digne-les-Bains (Fig. 1, stratigraphic interval RB001-113 in Fig. 12). Another important section is located on the west side of the Auran ravine, around $700 \mathrm{~m}$ south of the Ravin $\mathrm{du}$ Bès Section and $300 \mathrm{~m}$ southwest of the Bas Auran farm, in which this chronostratigraphic boundary can be studied through several hundred metres of outcrops (Ravin d'Auran Section, stratigraphic interval RA059-125 in Fig. 12). Some other outcrops, delimited by small vertical faults, lie upstream from the Robines ravine, on the west side, through $400 \mathrm{~m}$ towards Le Bès farm, between 800 and $900 \mathrm{~m}$ of altitude (Ravin des Robines Section, stratigraphic interval
RR001-067 in Fig. 12). These sections range from the Bomfordi Subzone (upper Bajocian) to the Tenuiplicatus Subzone (Aurigerus Zone, lower Bathonian) and are over $13 \mathrm{~m}$ thick (Sturani 1967; Pavia 1973; Torrens 1987; Innocenti et al. 1988; Olivero et al. 1997).

In the Bas Auran area, lower Bathonian deposits are made up of black or grey limestone beds alternating with marls usually known as 'Marno-calcaires à Cancellophycus', below the 'Terres Noires' Formation (Graciansky et al. 1982; Olivero 1994, 2003; Olivero \& Atrops 1996; Olivero et al. 1997). Petrographically and in terms of biofacies, they are relatively uniform mudstones to wackestones, with common ammonoids, scarce sponges and very scarce nautiloids, brachiopods, bivalves, belemnites, echinoids, crinoids and gastropods. From a micropalaeontological point 


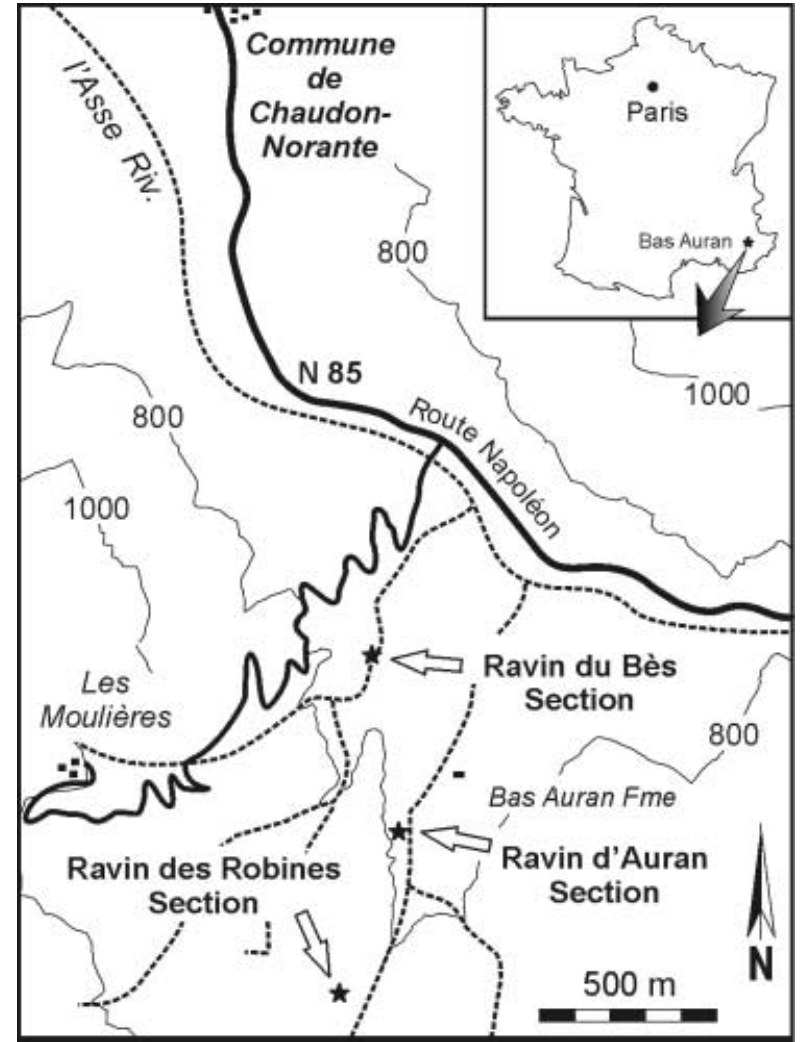

Fig. 1. Location map of the three stratigraphic sections referring to the Bajocian/Bathonian boundary in the Bas Auran area ('Alpes de Haute Provence' French department, SE France). From north to south, Ravin du Bès Section $\left(43^{\circ} 57^{\prime} 38^{\prime \prime} \mathrm{N}, 6^{\circ} 18^{\prime} 55^{\prime \prime} \mathrm{E}\right)$, Ravin d'Auran Section ( $\left.43^{\circ} 57^{\prime} 21^{\prime \prime} \mathrm{N}, 6^{\circ} 18^{\prime} 56^{\prime \prime} \mathrm{E}\right)$ and Ravin des Robines Section $\left(43^{\circ} 57^{\prime} 06^{\prime \prime} \mathrm{N}, 6^{\circ} 18^{\prime} 51^{\prime \prime} \mathrm{E}\right)$.

of view, the overall sedimentary facies shows a calcisphere-mudstone texture. The marls contain foraminifers, ostracods and molluscs (cephalopods, bivalves, gastropods) along with detrital minerals, quartz, muscovite and biotite (Corbin et al. 2000). The Bathonian deposits of this formation are interpreted as having been developed in a hemipelagic environment on the slope of the French Subalpine Basin, below storm wave base.

The main purpose of the present work is to describe and interpret from a taphonomic point of view the successive ammonoid fossil assemblages at the Bajocian/Bathonian boundary on the Bas Auran area, in order to test and improve the available data concerning biostratigraphic completeness, palaeoenvironmental setting and sequence stratigraphy. Over 500 ammonoid specimens, from 125 stratigraphic levels, through $13 \mathrm{~m}$ in thickness, of the upper Bajocian Parkinsoni Zone and lower Bathonian have been studied on the Bas Auran area. Most of these ammonoids are derived from collections previously studied for bio- and chronostratigraphic purposes by several authors (Sturani 1967; Pavia 1973; Innocenti et al. 1988). Moreover, new observations and field samplings of these sections allow the recognition of complementary data for taphonomy, stratigraphic continuity, palaeoenvironmental setting and sequence stratigraphy.

\section{Mechanisms of taphonomic alteration and results in ammonoids (Fig. 2)}

The taphonomic analysis of these ammonoid fossil assemblages includes over 50 preservational features mainly related to biostratinomic and synsedimentary modifications, according to the model of FernándezLópez (1997a, b, 2000).

Ammonoid remains are dominated by shells. Aptychi are very scarce and less than $1 \%$. Ammonoid shells are commonly recorded throughout the studied sections, but they rarely exceed $200 \mathrm{~mm}$ in diameter (less than 1\%; Fig. 3). Ammonoids are commonly preserved as concretionary internal moulds of resedimented shells.

Biostratinomic processes of biodegradationdecomposition were generally intense, as ammonoid shells usually lost the soft parts, aptychus and periostracum before burial. Aptychi have not been found within the ammonoid shells. Siphuncular tubes are generally disarticulated, due to intense and longlasting biostratinomic processes of biodegradation before burial.

Mechanisms of taphonomic alteration by incrustation show very low incidence. Shells bearing signs of intrathalamous or extrathalamous (Tintant 1984) and dense encrusting by organisms (such as serpulids, bryozoans or oysters) are virtually absent. Pisolitic or oncolitic ammonoids, ammonite half-lumps (Fernández-López et al. 2000), local micritic crusts or microbial stromatolitic laminae have not been observed. However, at the top of the 'Marnocalcaires à Cancellophycus' on the Bas Auran area, concretionary internal moulds, darker than the sedimentary matrix and covered by an argillaceous film of glossy appearance, as well as biogenic borings indicative of hard grounds (Zapfella) are common, associated with very scarce encrusting serpulids and manganese crusts, indicating the development of a stratigraphic discontinuity (Sturani 1967; Torrens 1987). Biogenic borings as well as remains of epilithic organisms occur on some concretionary internal moulds from levels RR002 and RR004 (Figs 4, 5).

Sedimentary infill of the ammonoid shells is generally complete up to the innermost whorls. 
MECHANISMS OF TAPHONOMIC ALTERATION and results in ammonites:

\section{BIODEGRADATION}

Body chambers with soft-parts

Body chambers with aptychus

Shells with periostracum

Shells with articulated siphuncular tube

INCRUSTATION

Shells with intrathalamous encrusting

Specimens with extrathalamous encrusting

Specimens with stromatolitic laminae

Ammonite half-lumps

SEDIMENTARY INFILL

Body chambers without sedimentary infill

Hollow ammonites

Homogeneous and complete sedimentary infill

Heterogeneous sedimentary infill

Siliciclastic pseudomorphosis of the shells

Sedimentary internal moulds with fill channel

SYNSEDIMENTARY MINERALIZATION

Calcareous concretionary internal moulds

Phosphatlc concretionary internal moulds

Glauconitic concretionary internal moulds

Pyritic internal moulds

Silicified concretionary internal moulds

Ammonite half-concretions

ABRASION

Internal moulds with truncation facets

Internal moulds with roll facets

Internal moulds with ellipsoidal facets

Internal moulds with annular furrows

BIOEROSION

Internal moulds with biogenic borings

SYNSEDIMENTARY DISSOLUTION

Shells without septa (hollow phragmocones)

Periostraca without either septa or walls

Concretionary internal moulds without septa

\section{TAPHONOMIC DISTORTION}

Complete shells

Incomplete phragmocones

Shells with opened fractures

Shells with closed fractures

Fragmentary internal mould

Moulds with discontinuous deformation by compaction

\section{REORIENTATION}

Shells with azimuthal reorientation

Internal moulds with azimuthal reorientation

Vertical shells

Vertical concretionary internal moulds

DISARTICULATION

Disarticulated aptich

Disarticulated siphuncular tubes

Disarticulated internal moulds

\section{DISPERSAL}

Taphonic populations of type 1

Taphonic populations of type 2

Taphonic populations of type 3

REGROUPING

Encased shells

Imbricated internal moulds

Alignment of concretionary internal moulds

Ammonite packing

Stratigraphical persistence

\section{REMOVAL}

Accumulated elements

Resedimented elements

Reelaborated elements

Fig. 2. Mechanisms of taphonomic alteration and results in ammonoids of the Bajocian/Bathonian boundary on the Bas Auran area (France).

Internal moulds of shells completely filled with relatively homogeneous sediments are predominant. However, internal moulds commonly show asymmetrically preserved flanks, varying in clay content (Fig. 6). Resedimented shells present a higher proportion of clay in the upper flank, with respect to the

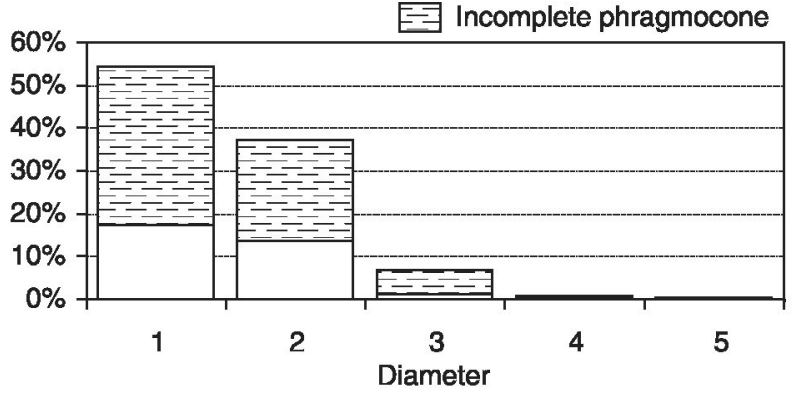

Fig. 3. Relative size-frequency histogram (relative shell diameters; Dmax. $=305 \mathrm{~mm}$ ) for 400 ammonoids, from the Bas Auran area, Bomfordi and Parvum subzones, displaying the proportion of incomplete phragmocones and shells bearing complete or partia body chamber. Small ammonoid shells are dominant, although generally correspond to incomplete phragmocones.

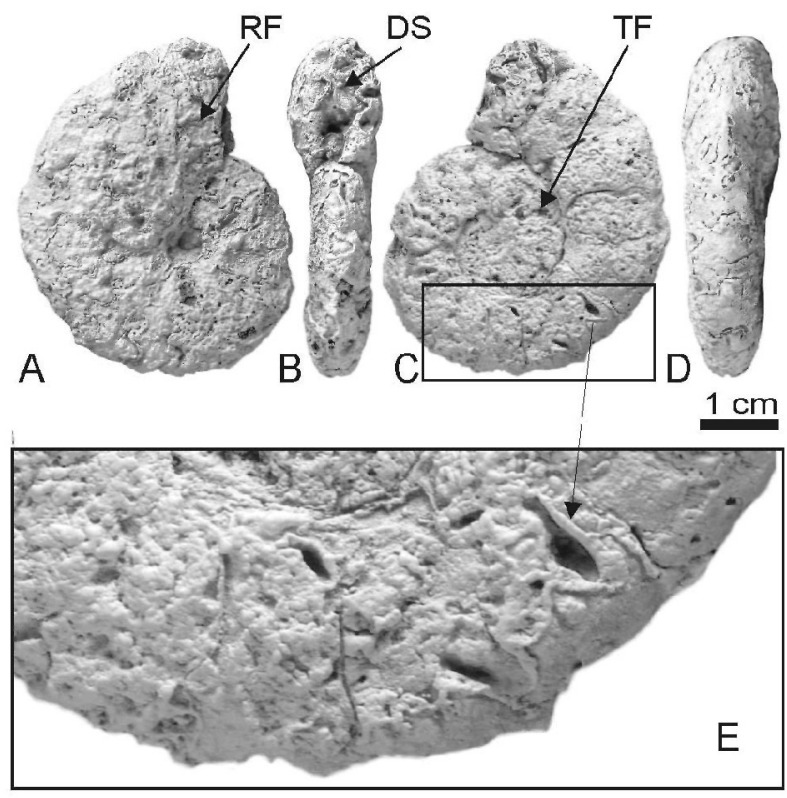

Fig. 4. Incomplete phragmocone of Phylloceras sp. Ravin des Robines Section. Tenuiplicatus Subzone, Aurigerus Zone, lower Bathonian. Specimen RR001/1, whitened with magnesium oxide prior to photography. Lateral $\square \mathrm{A}, \mathrm{C}$, oral $\square \mathrm{B}$ and ventral $\square \mathrm{D}$ views. $\square \mathrm{E}$. Detailed view of biogenic borings on the right flank. Manganese- and iron-crust-coated, calcareous concretionary internal mould, showing a disarticulation surface (DS) at the end of the preserved outer whorl that represents a structural discontinuity with the sedimentary matrix, a roll facet of abrasion (RF) capping the original ornamentation, and a truncation facet (TF) in the right whorl side capping diverse biogenic borings. Acrothoracican barnacles (ichnogenus Zapfella) preferentially colonized the right whorl side of this concretionary internal mould, during reelaboration and before final burial.

stratification, whereas reelaborated internal moulds can show this geopetal feature reversed in position. The sedimentary infill is similar in petrological composition and texture to the sedimentary matrix. Exceptionally (less than 10\%), in reelaborated internal moulds, the sedimentary infill may be separated from the matrix by a sharp and erosive structural 

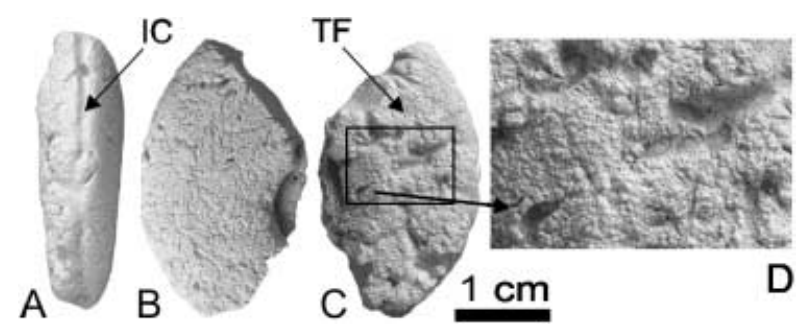

Fig. 5. Incomplete phragmocone of Lissoceras sp. Ravin des Robines Section. Tenuiplicatus Subzone, Aurigerus Zone, lower Bathonian. Specimen RR001/2, whitened with magnesium oxide prior to photography. Ventral $\square$ A, and lateral $\square$ B and C views. $\square$ D. Detailed view of biogenic borings on the right flank. Fragmentary internal mould showing a fill channel (IC) in the external region and a truncation facet (TF) on the right whorl side. The fill channel was formed by draft-current processes during resedimentation of the shell on the seafloor, before initial burial. The homogeneous and calcareous sedimentary infill reaches the inner whorls. The lateral truncation facet was due to abrasion processes during reelaboration of the concretionary internal mould. Acrothoracican barnacles (ichnogenus Zapfella) colonized the right whorl side of this concretionary internal mould, before final burial.
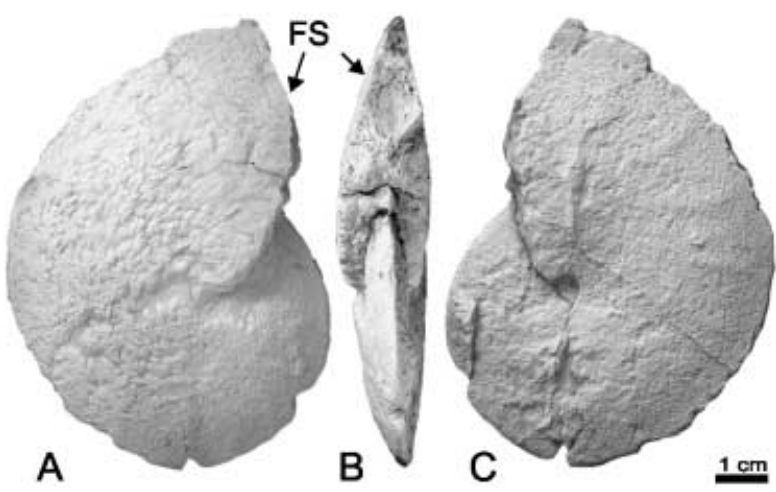

Fig. 6. Incomplete phragmocone of Oxycerites limosus (Buckman) [M]. Ravin d'Auran Section. Parvum Subzone, Zigzag Zone, lower Bathonian. Specimen RA057/1, whitened with magnesium oxide prior to photography. Lateral $\square \mathrm{A}, \mathrm{C}$ and oral $\square \mathrm{B}$ views. Example of ammonite half-concretion, a calcareous concretionary internal mould, showing a fracture surface (FS) in the oral region, and a compressed right whorl side $\mathrm{C}$. The fracture surface was due to taphonomic distortion processes during reelaboration of the concretionary internal mould. The planar right whorl side resulted from continuous deformation of clay portions of sedimentary infill by diagenetic compaction.

discontinuity. Sedimentary internal moulds showing a local infill channel on the ventral region (FernándezLópez 2005) are very scarce and associated with the development of soft grounds in levels RR002 and RR004 (Fig. 5) or present in Cadomitidae from the intervals RB071-070 and RA085-082 (level 23 in Sturani 1967 and Innocenti et al. 1988; Fig. 12). Phragmocones without sedimentary infill (i.e. hollow ammonites in Fig. 2) are scarce (10\%). Shells with heterogeneous sedimentary infill are virtually absent. Body chambers without sedimentary infill or siliciclastic pseudomorphosis of the shells are absent,
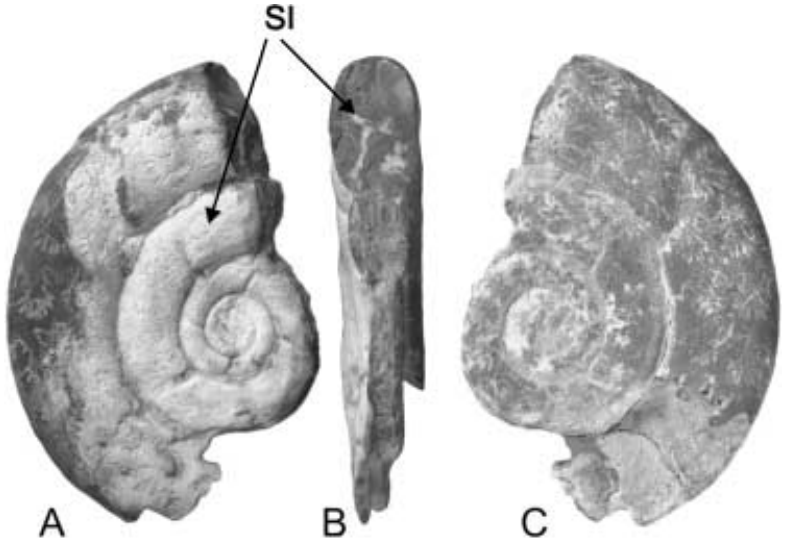

$1 \mathrm{~cm}$

Fig. 7. Incomplete phragmocone of Nannolytoceras sp. Ravin des Robines Section. Parvum Subzone, Zigzag Zone, lower Bathonian. Specimen RR041/1. This specimen is not whitened with magnesium oxide prior to photography. Lateral $\square \mathrm{A}, \mathrm{C}$ and oral $\square \mathrm{B}$ views. Calcareous internal mould showing silicified portions (SI) preferentially developed in left whorl side. The homogeneous and calcareous sedimentary infill reaches the innermost whorls.

too. This abundance of complete sedimentary internal moulds of ammonoid shells is indicative of both low rate of sedimentation and low rate of sediment accumulation during biostratinomic processes (Fernández-López et al. 2002; Fernández-López 2005).

Processes of synsedimentary mineralization were intense. Ammonoids are generally preserved as calcareous concretionary internal moulds of resedimented shells (90\%). Partially or locally phosphatized concretionary internal moulds are common (up to $50 \%$ ). Complete concretionary internal moulds of the body chamber and phragmocone are abundant, and indicative of early mineralization and low rate of sediment accumulation. Calcareous half-concretions (Fernández-López 1997a, b) or asymmetrically compressed concretions of ammonoid shells are common (up to $60 \%$ ). Minute pyritic internal moulds of the innermost whorls or pyrite linings of some portions of the whorl or the flank, millimetric in size, occur (less than $16 \%$ of the total recorded elements) in several marly intervals (RA112-RA110, RA088RA082, RA050-RA044, RA038-RA034). Silicified concretionary internal moulds are very scarce (less than 5\%, Fig. 7), although they locally occur included in mudstone to wackestone beds of sponges (RR043, RR041 and RR039). Glauconitic concretionary internal moulds are absent.

Traces of abrasion on shells and internal moulds are common. Internal moulds with abrasion ellipsoidal facets or annular furrows are virtually absent (Fernández-López \& Meléndez 1995). However, abrasion roll facets preferentially developed on the most prominent portions of concretionary internal 


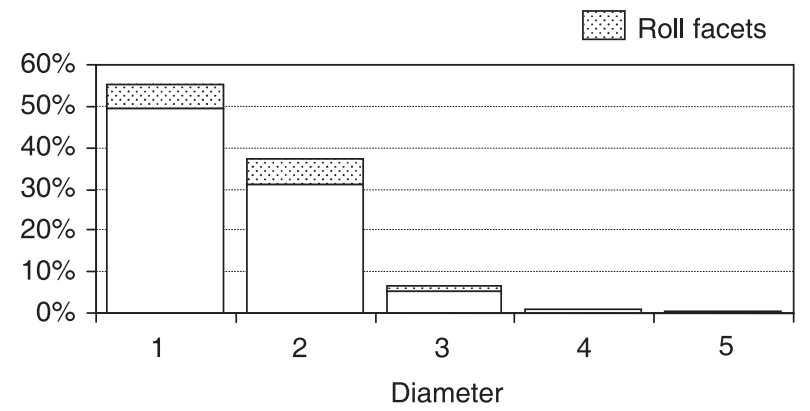

Fig. 8. Relative size-frequency histogram (relative shell diameters; Dmax. $=305 \mathrm{~mm}$ ) for 400 ammonoids, from the Bas Auran area, Bomfordi and Parvum subzones, displaying the proportion of internal moulds bearing abrasion rounding facets. Roll facets occur in highest proportion among small ammonoid internal moulds.

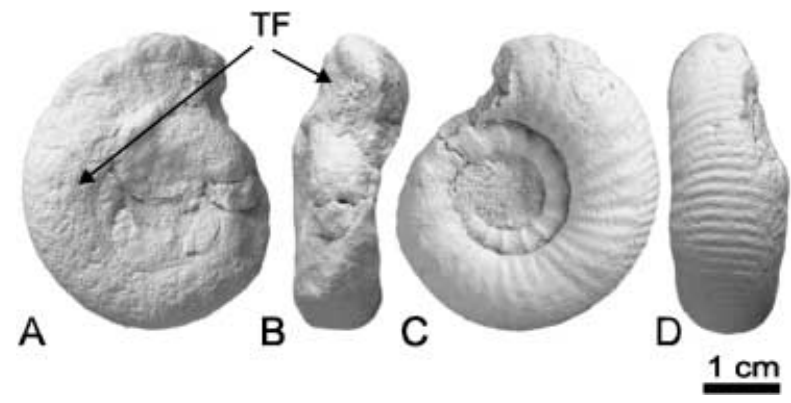

Fig. 9. Incomplete phragmocone of Zigzagiceras sp. Ravin des Robines Section. Macrescens Subzone, Zigzag Zone, lower Bathonian. Specimen RR028/1, whitened with magnesium oxide prior to photography. Lateral $\square$ A, C, oral $\square$ B and ventral $\square \mathrm{D}$ views. Calcareous, concretionary, internal mould showing a truncation facet (TF) in the left whorl side. The truncation facet is cutting septa of the phragmocone and represents a structural discontinuity with the sedimentary matrix. Innermost whorls of the phragmocone (diameter less than $9 \mathrm{~mm}$ ) are not preserved. The hollow camerae were destroyed during reelaboration, and their volume was occupied by sedimentary matrix during final burial.

moulds are relatively common among the small ammonoids (Fig. 8) of the highest levels (RB038RB002, RR048-RR002), although they occur in middle intervals (RB092-RB040, RA102-RA050). Truncation facets on a flank (Fig. 9) are common (less than 20\%), particularly in ammonoids of the highest levels (RB038-RB002, RR048-RR002), but they are scarce in middle intervals (RB092-RB040, RA102-RA050). An abraded side seems to occur preferentially among the largest-size ammonoids. The occurrence of this worn surface is due to the greater mechanical stability and the greater probability of abrasion of the largest specimens during the processes of synsedimentary exhumation by sedimentary winnowing.

Concretionary internal moulds of phragmocones with calcitic septa are the dominant fossils. Hollow phragmocones (i.e. shells without septa; sensu Seilacher

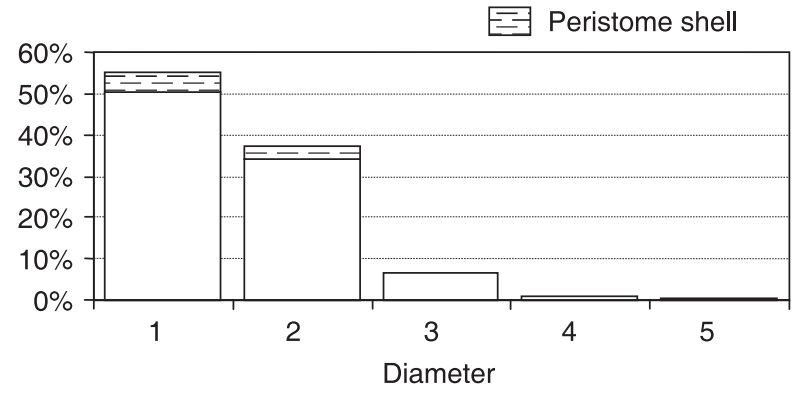

Fig. 10. Relative size-frequency histogram (relative shell diameters; Dmax. $=305 \mathrm{~mm}$ ) for 400 ammonoids, from the Bas Auran region, Bomfordi and Parvum subzones, displaying the highest proportion of shells bearing peristome among the categories of lowest diameter.

et al. 1976; Maeda \& Seilacher 1996) are very scarce, usually compressed by increasing sedimentary loading during diagenesis, and preferentially located on the lowest stratigraphic levels (RB114-RB042, RA124RA048). Septa of hollow phragmocones may have disappeared by early dissolution, while the walls of the shells still persisted, giving rise to compressed elements showing discontinuous deformation of the wall by gravitational compaction. Concretionary internal moulds without septa (Fernández-López 2000), indicative of synsedimentary dissolution of septa, are absent. No signs of biostratinomic or synsedimentary dissolution of the aragonitic remains have been recognized. Aragonitic shells have been dissolved during later diagenetic processes. Moldic porosity resulting from dissolution processes of shells and septa has been partially filled by spar cement in these deposits.

Ammonoid assemblages show a high proportion of incomplete phragmocones (up to 66\%) and scarce complete shells with peristome (7\%; Fig. 10). Fragmented specimens of resedimented shells are abundant, but generally bearing no signs of rounding, incrustation or bioerosion, due to low turbulence near the water/sediment interface. Reelaborated internal moulds are common (less than 35\%), often showing disarticulation surfaces along septa with sharp margins or geopetal sedimentary infill reversed in position. Undeformed, concretionary internal moulds, showing no evidence of compaction (20\%), occur preferentially in some clay intervals (levels RA094, RA082, RA078, RA076, RA074, RA072) and on the highest levels (RB038-RB002, RR048-RR002). Internal moulds usually display traces of continuous (70\%) or discontinuous (10\%) deformation by diagenetic compaction. Discontinuous deformations, with sign of breaking of the shell and compression by diagenetic compaction, or continuous deformations on the flanks of internal moulds commonly are not 
arranged in symmetry, as the degree of deformation is proportional to the clay content of sedimentary infill.

Ammonoids commonly appear scattered in the deposits, showing no pattern of imbricated (arranged so as to overlap each other) or encased (enclosed within another one) regrouping. Ammonoid abundance and concentration increase towards the top of the 'Marno-calcaires à Cancellophycus' (cf. Sturani 1967). Concave up orientation of fossils has not been observed. Concretionary internal moulds and shells included in limestone beds may be in vertical attitude (10\%). However, concretionary internal moulds and shells included in marly intervals are horizontally reoriented and may form alignments. The degree of ammonoid packing $(27.5 \%$, estimated by the difference between the number of specimens and the number of fossiliferous levels divided by the number of fossiliferous levels; Fernández-López et al. 1999) displays low values, but the ammonoid stratigraphic persistence $(100 \%$, estimated by the proportion of fossiliferous levels) displays very high values.

Taphonic populations of type 3 are dominant, whereas types 2 or 1 virtually absent (FernándezLópez 1995; Fernández-López et al. 1999). These taphonic populations of type 3 show uni- or polymodal and asymmetric distribution of size frequencies, with negative skew. Shells of juveniles are absent and adults are predominant. Taphonic populations of type 1, dominated by juveniles and indicative of eudemic taxa and autochthonous biogenic production, have not been recognized (cf. Fernández-López \& Gómez 2004; Fernández-López \& Meléndez 2004a, b; Reboulet et al. 2003, 2005).

Ammonoid associations are dominated by reworked elements (i.e. resedimented and reelaborated elements sensu Fernández-López 1991, 1995). Accumulated elements, showing no evidence of reworking after laying on the seafloor, are very scarce $(5 \%)$ and associated with the lowest stratigraphic intervals (RB114-RB092 and RA124-RA102). Reelaborated internal moulds (i.e. exhumed and displaced before their final burial) are locally present (up to 35\%), showing structural discontinuity with, and darker colour than, the including deposit. Resedimented shells, displaced on the seafloor before their burial, are dominant (60\%). Criteria to recognize reelaborated ammonites are: the petrographic difference between the filling and the enclosing sedimentary rock; the presence of a structural discontinuity between the sedimentary filling and the enclosing rock; the presence of inverted geopetal filling, disarticulation surfaces along the boundary between contiguous chambers of the phragmocone or between the phragmocone and the body chamber, fracture surfaces or abrasion surfaces on the internal mould, coating by ferruginous or manganese crusts, and traces of bioerosion or encrusting organisms. Reelaborated internal moulds of ammonites usually maintain their original shape without traces of extensive compression by diagenetic compaction. Reelaborated fossils occur preferentially among the smallest-size ammonoids of some clay intervals and in the highest stratigraphic intervals (RB038-RB002, RR048-RR002). This differential reelaboration was due to the greater mechanical instability and the greater probability of displacement on the seafloor of the smallest specimens. The degree of reworking or removal (i.e. the ratio of reelaborated and resedimented elements to total recorded elements) increases upwards and can reach $100 \%$ in many of the highest stratigraphic intervals. However, the degree of taphonomic heritage (i.e. the ratio of reelaborated elements to total recorded elements) is relatively low (less than 35\%). The degree of taphonomic condensation (i.e. mixture of fossils of different age or different chronostratigraphic units) reaches very low to zero values in the Bajocian/ Bathonian transition. Ammonoid mixed assemblages composed of specimens representing several biohorizons in a single bed or clay interval have not been identified, except in level 002 (boundary between Recinctus and Tenuiplicatus subzones).

\section{Ammonoid taphofacies and elementary sequences (Fig. 11)}

Marly intervals show a lower value of thickness than limestone intervals in the studied sections $(N=116$; marl mean $=10.6 \mathrm{~cm}$, limestone mean $=12.3 \mathrm{~cm}$ ). The Bomfordi Subzone, more than $5 \mathrm{~m}$ in thickness, yields a total of more than 21 limestone intervals thicker than $1 \mathrm{~cm}$; of these beds, 2 (9.5\%) show widths less than $1 \mathrm{~m}$. In this subzone, most limestone intervals thicker than $10 \mathrm{~cm}$ are simple beds. The Parvum Subzone, slightly less than $5 \mathrm{~m}$ in thickness, yields a total of about 23-26 limestone intervals thicker than $1 \mathrm{~cm}$, in the Ravin du Bès Section and Ravin d'Auran-Ravin des Robines sections respectively; of these beds, 3-1 (13.4-3.6\%) show widths less than $1 \mathrm{~m}, 20(86.9-76.9 \%)$ are mudstones and 6 wackestones (13.1-23.1\%) of ammonoids. Most limestone intervals thicker than $10 \mathrm{~cm}$ are complex, variably amalgamated stacks of two or three lenses or simple beds. The Macrescens and Recinctus subzones, about $3 \mathrm{~m}$ in thickness, yield a total of about 12-16 limestone beds, in the Ravin du Bès Section and Ravin d'Auran-Ravin des Robines sections respectively, being 2-1 (16.6 and 6.2\% respectively) less than 


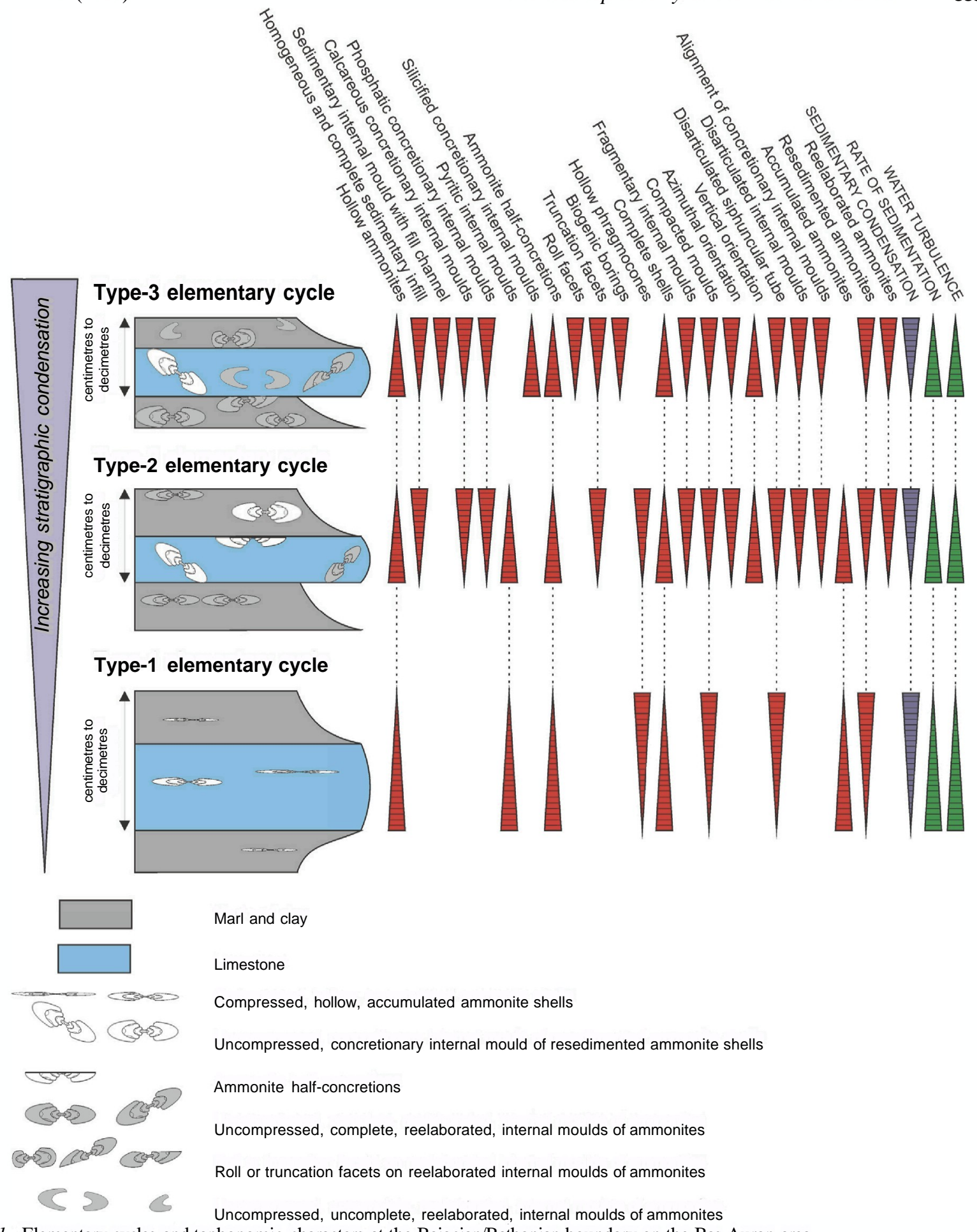

Fig. 11. Elementary cycles and taphonomic characters at the Bajocian/Bathonian boundary on the Bas Auran area.

$1 \mathrm{~m}$ in width, 6-10 mudstones (50.0-62.5\%) and 6 wackestones (50.0-37.5\%) of ammonoids and sponges. Limestone intervals thicker than $10 \mathrm{~cm}$ are complex, variably amalgamated stacks of two or three lenses or simple beds. Consequently, the strong similarities in thickness, number and proportion of beds within subzones between Ravin du Bès Section (RB) and Ravin d'Auran-Ravin des Robines sections (RA-RR) sections suggest that the patterns of bed distribution are of regional extent. Nevertheless, the total thickness and number of elementary cycles of the lower Bathonian on the Ravin d'Auran-Ravin des Robines sections is greater than on the Ravin du Bè̀s Section and, consequently, accommodation space and water depth must have been greater in the Ravin d'AuranRavin des Robines area. 


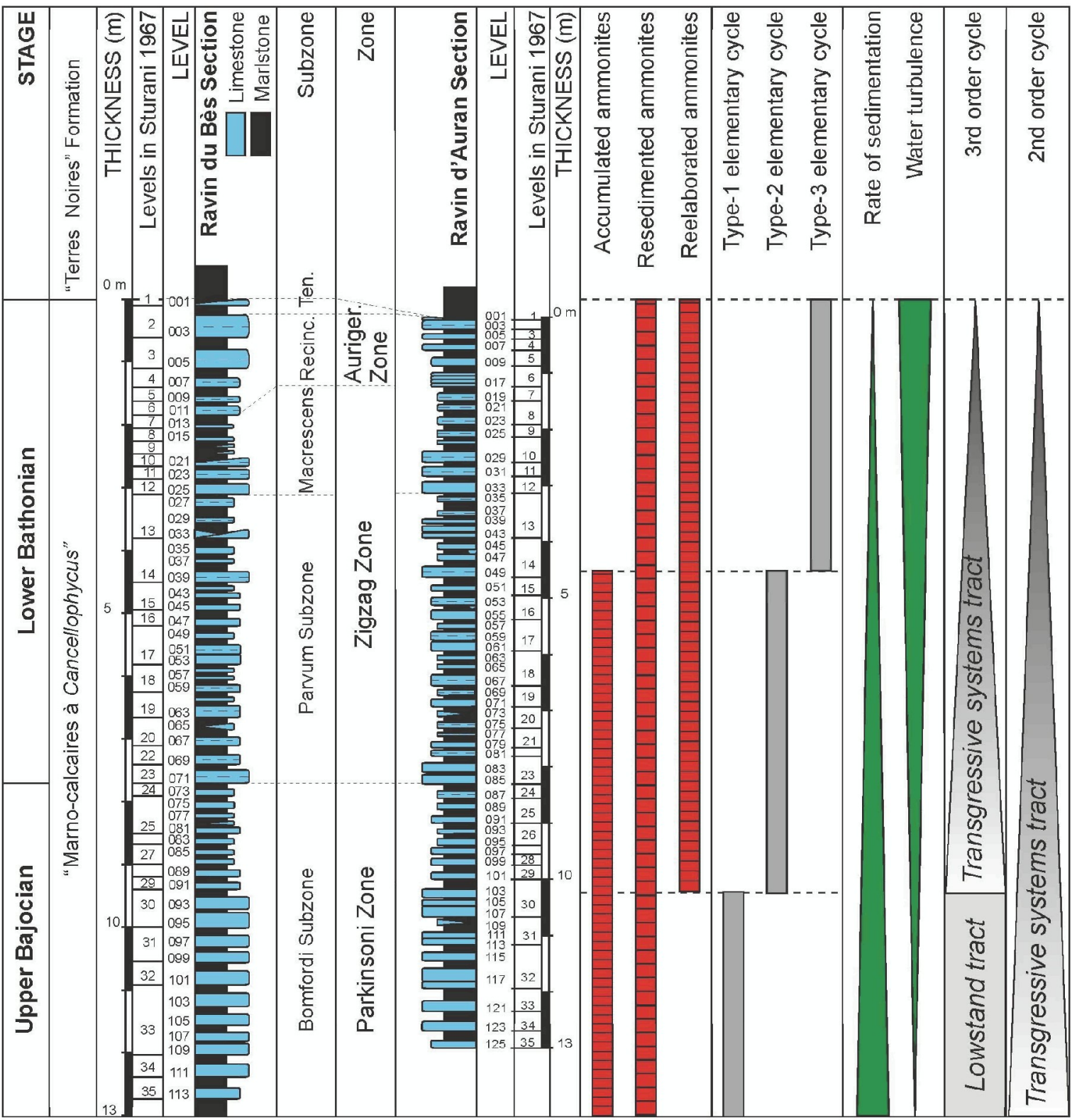

Fig. 12. Ammonoid biochronostratigraphic data at the Bajocian/Bathonian boundary in the Ravin du Bès and Ravin d'Auran sections, indicating ammonoid preservation states, types of elementary cycles, and system tracts of third- and second-order cycles.

In the Bas Auran area, three types of centimetre to decimetre scale, elementary cycles may be recognized (Fig. 11).

\section{Type-1 elementarycycles}

These cycles are composed of mudstone beds ranging in thickness from 9 to $28 \mathrm{~cm}$, and marly intervals from 2 to $30 \mathrm{~cm}$ (RB114-RB093 and RA125-RA103) of the Bomfordi Subzone. Overall mean thickness of limestone-marl cycles is $29.4 \mathrm{~cm},(N=21)$. Mudstone limestones make up the greatest proportion of thickness (51\% for limestones and $49 \%$ for marls). Thin, discontinuous to lenticular limestones, showing widths less than $1 \mathrm{~m}$, are very scarce. Limestones correspond to homogeneous and simple beds that show a gradational base and upper contact. Soft-ground bioturbation textures are common. Firm-ground bioturbation structures and hard-ground borings are absent.

Macrofossils are scattered. Ammonoid fossil assemblages are dominated by resedimented elements, displaced on the sea bottom before their burial. Accumulated elements, showing no evidence of reworking after laying on the sea bottom, may be locally common. Reelaborated internal moulds are virtually absent. The degree of reworking is variable, but the degree of taphonomic heritage is very low to $0 \%$. The degree of taphonomic condensation is nil in all cases.

Phragmocones are normally unfilled by sediment. Complete concretionary internal moulds of the 
body chamber and phragmocone, indicative of low rates of sedimentation and sediment accumulation, are scarce. In contrast, compressed, partial internal moulds of body chambers (i.e. hollow ammonites), indicative of very rapid sedimentary infill and high rate of sedimentation, are abundant. Concretionary internal moulds formed by early cementation processes are very scarce or absent. Signs of abrasion and bioerosion on shells and internal moulds, as well as disarticulation surfaces or truncation facets, are virtually absent.

Concretionary internal moulds showing septa of the phragmocone are very scarce or absent. The septa and the wall of the shell can disappear by early dissolution, giving rise to compressed elements showing continuous deformation by gravitational compaction. The dominant fossils are crushed ammonoids. Hollow ammonites (i.e. showing no sedimentary infill in the phragmocone) and hollow phragmocones (i.e. without septa) are the dominant fossils, but they are usually compressed by gravitational compaction. Hollow ammonites maintaining their original volume and form are scarce, as a result of the high rate of sedimentation, slow early cementation and rapid compaction.

Complete shells are common. Fragmentary shells can occur, but bearing no signs of rounding, incrustation or bioerosion during resedimentation processes on the sea bottom, due to the low turbulence near the water/sediment interface. Shells are not azimuthally reoriented, but they tend to be horizontal on the bed surface. Siphuncular tubes are usually disarticulated. Planar fabric (Lenoble \& Bertran 2004), normal grading, alignment or concave up orientation of fossils are absent. There is no evidence for fluid, soup- (water saturated) substrates, such as vertically compressed shells, compacted while held in vertical position by confining sediment (cf. Hudson \& Martill 1991).

In this taphofacies, the fine-grained nature of the mudstones suggests deposition in a low-energy setting. Currents were very slight or absent, but scattered ammonoid shells were horizontally reoriented and fragmented by resedimentation after their accumulation on soft grounds. Processes of early mineralization were not intense. Cementation of limestone intervals was not early in diagenesis as ammonoids are usually crushed. These elementary cycles of type- 1 do not show evidence for prolonged time-averaging under sediment-starved conditions.

\section{Type-2 elementary cycles}

These cycles are constituted by lime mudstone to wackestone beds ranging in thickness from 5 to
$22 \mathrm{~cm}$, and marly intervals from 2 to $33 \mathrm{~cm}$ (RB092RB039 and RA102-RA049) of the Bomfordi and Parvum subzones. Overall mean thickness of limestone-marl cycles is $21.5 \mathrm{~cm}(N=54)$. Limestones and marly intervals display similar proportions of thickness (49\% for limestones and 51\% for marls). Thin, discontinuous to lenticular lime mudstones, less than $1 \mathrm{~m}$ in width, occur. Limestone intervals do not represent single events and, usually, comprise two amalgamated beds. The boundaries of limestones are commonly gradational, but the base in some beds is sharper than the top. Bioturbation structures typical of soft ground (Zoophycos, Chondrites) and soft to firm ground (Planolites) occur. Tubular and narrow (1-3 mm diameter), pyrite-filled burrows with various orientations are locally common. Hard-ground borings are absent.

Macrofossils are scattered. Ammonoid fossil assemblages are dominated by reworked elements (comprising reelaborated and resedimented elements sensu Fernández-López 1991, 1995). Non-reworked or accumulated elements, showing no evidence of removal after laying on the sea bottom, are scarce or absent. Reelaborated internal moulds, exhumed and displaced before their final burial, may be locally common. Resedimented shells, displaced on the sea bottom before their burial, are dominant. The degree of reworking can reach $100 \%$ but the degree of taphonomic heritage is usually low. The degree of taphonomic condensation reaches very low to zero values in all cases.

Complete concretionary internal moulds of the body chamber and phragmocone, indicative of lasting sedimentary infill under conditions of low rates of sedimentation and sediment accumulation, are common. In contrast, compressed, partial internal moulds of body chambers (i.e. hollow ammonites), indicative of brief and very rapid burial under conditions of high rate of sedimentation, are scarce. Body chambers and phragmocones are normally filled by relatively homogeneous sediment, although the lower portions are more calcareous and the upper portions are more argillaceous than the sedimentary matrix. Concretionary internal moulds are calcareous and phosphatized. In the most marly intervals, pyritic internal moulds of the innermost whorls of resedimented shells may be locally common. Signs of abrasion and bioerosion on shells and internal moulds are very scarce. Reelaborated internal moulds can show disarticulation surfaces and fractures; however, truncation or roll facets are very scarce.

Concretionary internal moulds showing septa of the phragmocone are common. Hollow phragmocones are scarce, and they are usually compressed by increasing sedimentary loading during diagenesis. 
More or less crushed ammonoids are dominant. Calcareous half-concretions or asymmetrically compressed concretions of ammonoid shells are common.

Fragmentary shells are dominant. Reelaborated internal moulds rarely show disarticulation surfaces with sharp margins, but no signs of rounding by abrasion or bioerosion, due to low turbulence at the water/sediment interface. Azimuthally reoriented shells and concretionary internal moulds are abundant in marly intervals. Ammonoids with their long axes parallel to bedding surface are dominant in marls. Normal grading of fossils occurs in limestone beds, but planar fabric, alignment or concave up orientation of fossils are absent.

The fine-grained nature of the mudstones suggests deposition in a low-energy setting. Laminated marls were developed on a sea bottom under sub-oxic conditions. The abundant reoriented shells, aligned with their long axes parallel to the bedding surfaces, however, imply sedimentary surfaces of soft ground stage and very slight currents. Processes of early mineralization were not intense. The cementation of the limestone intervals was not early in diagenesis as ammonoids are usually more or less crushed. The sharp, irregular bases of simple beds and the normal grading of reworked concretions suggest that carbonate inputs were affected by tractive currents, scouring and redeposition. The occurrence of reelaborated ammonoids in marly intervals implies that some form of tractive current flow or winnowing affected the burial of concretionary internal moulds. The common occurrence of homogeneous concretionary internal moulds of phragmocones, completely filled with sediment, is indicative of low rate of sedimentation and low rate of sediment accumulation. Consequently, these elementary cycles of type- 2 show local evidence for time-averaging under sedimentstarved conditions.

\section{Type-3 elementary cycles}

These cycles are composed of lime mudstone to wackestone beds, with ammonoids and sponges, ranging in thickness from 5 to $35 \mathrm{~cm}$, and marly intervals from 1 to $20 \mathrm{~cm}$ (RB038-RB001 and RR048RR001) occur in the Parvum, Macrescens, Recinctus and Tenuiplicatus subzones. Overall mean thickness of limestone-marl cycles is $20.6 \mathrm{~cm}(N=42)$. Limestone intervals make up the greatest proportion of thickness (55\% for limestones and $45 \%$ for marls). Thin, discontinuous to lenticular lime mudstones or wackestones, showing widths less than $1 \mathrm{~m}$, are common. Limestone intervals may correspond to simple or complex beds, comprising two or three amalgamated beds, and show sharp boundaries.
Limestone intervals display sharp bases and commonly burrowed tops. Soft to firm ground bioturbation structures are common (Thalassinoides, Diplocraterion, Planolites). Soft-ground bioturbation structures (Zoophycos, Chondrites) occur also. Hard-ground borings (Zapfella) are locally common, on the topmost bed (level 001). Ammonoids and sponges that make up the limestones also occur in marls. Reworked remains of centimetre- or decimetre-sized sponges, developed in cup and tube morphologies, are predominant. However, several solitary, dish-shaped sponges in life position have been observed included in marly intervals and cemented to the tops of some limestone beds (RR045).

Macrofossils are scattered. Ammonoid fossil assemblages are dominated by reelaborated and resedimented elements. Non-reworked or accumulated elements, showing no evidence of removal after laying on the sea bottom, are absent. Reelaborated internal moulds may be dominant. Resedimented shells are common. The degree of reworking and the degree of taphonomic heritage can reach 100\%. However, the degree of taphonomic condensation only reaches very low values. Ammonoid mixed assemblages composed of specimens representing two biozones or biohorizons have been identified in level RR002 (boundary between Recinctus and Tenuiplicatus subzones) and the biostratigraphic completeness does not reach $100 \%$.

Complete concretionary internal moulds of the body chamber and phragmocone, indicative of low rates of sedimentation and sediment accumulation, are abundant. In contrast, compressed, partial internal moulds of body chambers (i.e. hollow ammonites), indicative of very rapid burial and high rate of sedimentation, are very scarce. Concretionary internal moulds are calcareous and phosphatized. Signs of abrasion and bioerosion on shells and internal moulds are very common. Reelaborated internal moulds can show disarticulation surfaces and fractures; less commonly and associated with scours and abrasion sedimentary surfaces, they can show truncation or roll facets.

Concretionary internal moulds showing septa of the phragmocone are the dominant fossils. Hollow phragmocones are very scarce, and they are usually compressed by increasing sedimentary loading during diagenesis. Uncrushed ammonoids are dominant.

Fragmentary shells are common. Reelaborated internal moulds commonly show disarticulation surfaces with sharp margins. Fragmentary internal moulds also occur, bearing signs of rounding by abrasion or bioerosion. Shells and concretionary internal moulds are azimuthally reoriented and may form alignments in marly intervals. Planar 
fabric by shells and internal moulds occur in marls. In contrast, normal grading of fossils is common in limestone beds.

The abundance of reelaborated internal moulds suggests deposition in a relatively high-energy setting. Ichnofossils and some taphonomic features (e.g. abundance of complete sedimentary internal moulds and the occurrence of reelaborated concretionary internal moulds bearing sedimentary infill channels) imply development of sedimentary surfaces of firm-ground stage and episodes of non-deposition or hiatus. Currents were slight, but some reelaborated ammonoids developed truncation and roll facets. Processes of early mineralization were intense. The cementation of most of the limestones was early in diagenesis as ammonoids are usually uncrushed. These elementary cycles of type-3 show taphonomic evidence for prolonged time-averaging under sediment-starved conditions.

In summary, sediments of these three types of sequences are interpreted as having been deposited in a hemipelagic environment, below wave base. However, the presence of reelaborated ammonoids implies that some form of current flow or winnowing affected the burial of concretionary internal moulds. Currents were slight, but concretionary internal moulds of ammonoids were disarticulated and azimuthally reoriented on soft or firm grounds through reelaboration. The formation of such calcareous concretions must have taken place either on the sea-floor contemporaneously with the sedimentary process or else within the sediment during the early diagenesis. Episodes of lower rates of sedimentation and sediment accumulation favoured a higher degree of bioturbation and reworking of ammonoid shells. Reelaboration processes (i.e. exhumation and displacement of remains before their final burial) and the activity of burrowing organisms are the main factors that induced the development of ammonoid associations showing a high degree of taphonomic heritage, but the degree of taphonomic condensation is very low on a geochronologic time-scale. Concretionary internal moulds of ammonoids were developed on the sea bottom, under oxic to sub-oxic conditions. Although the calcareous benthos is very scarce, the presence of abundant burrowing textures and structures suggests aerobic to dysaerobic biofacies. Ichnofossils such as Zoophycos suggest dysaerobic conditions (Bromley 1996; Olivero 1994; Olivero \& Gaillard 1996). The absence of pyritic ammonoids other than resedimented shells suggests that anaerobic conditions did not develop near the sedimentary surface. The limestone intervals, displaying sharp bases and normal grading of reelaborated concretionary internal moulds, were affected by tractive currents, scouring and redeposition. Moreover, reelaborated ammonoids and reworked concretions included in some beds, showing the base sharper than the top, could be mobilized by massive sliding. In contrast, the marly intervals were affected by scouring, winnowing and redeposition, as suggested by the occurrence of planar fabric by shells and internal moulds and the alignment of concretionary internal moulds. However, lateral transport of taphonomic elements would be very limited, taking into account the taxonomic similarity of palaeontological content between limestone beds and marly intervals, the similarity in petrological composition and texture between ammonoid sedimentary infill and sedimentary matrix, and the preservation of some sponges in life position.

\section{Palaeoenvironmental setting and sequence stratigraphy}

The Bas Auran area was located in the French Subalpine Basin, on the proximal part of the southeuropean Tethys margin. The depositional profile was a submarine slope that dipped northward from the Provence Platform, produced by Tethyan rifting. In the Mesozoic successions of the basin, made up of subpelagic, bed-scale limestone-marl alternations, second- to sixth-order cycles may be recognized (Ferry \& Mouterde 1989; Ferry et al. 1989, 1991; Mouterde et al. 1989; Zany et al. 1990; Ferry 1991; Ferry \& Dromart 1991; Graciansky et al. 1993, 1998; Ferry \& Mangold 1995; Olivero \& Atrops 1996; Olivero et al. 1997; Hardenbol et al. 1998; Jacquin et al. 1998).

From a geochemical point of view, several authors have emphasized that the manganese content of pelagic carbonates is related to second-order sealevel changes in the south-eastern basin of France during the Jurassic period. The main transgressive phases are marked by a manganese content increase, whereas the regressive phases are characterized by decreasing trends (Corbin et al. 2000). In the ChaudonNorante section, $4 \mathrm{~km}$ north of Bas Auran area, the early Bathonian (Zigzag Zone) maximum transgression is marked by sedimentary condensations, associated with high manganese content (from 300 to $1370 \mathrm{mg} \mathrm{kg}^{-1}$ ). In contrast, the middle and late Bathonian regressive phase coincide with low manganese content periods. These stratigraphical patterns in divalent manganese can be of either local or regional significance, the manganese being concentrated, most probably as a very early diagenetic phase, only in oxygen-depleted waters that typically underlie zones of elevated organic productivity (Jenkyns et al. 2002). 
Taphonomic analysis of ammonoid fossil assemblages and taphofacies are of stratigraphic interest since they provide an independent test of the palaeoenvironmental cycles inferred in sequence stratigraphy (Fürsich \& Oschmann 1993; Brett 1995, 1998; Fernández-López 1997b, 2000; Courville \& Collin 2002). Palaeontological criteria suggest that seafloor conditions recorded by marly and limestone intervals of the 'Marno-calcaires à Cancellophycus', at least in lower Bathonian deposits, were not highly differentiated in terms of depth. The taxonomic similarity in fossil content of the two lithologic phases suggests deposition in about the same environments. Limestone intervals represent episodes of event sedimentation in relatively high-energy environments. Simple limestone beds are composed of expanded deposits, developed under increased energy conditions, which are primarily the product of single abrupt episodes of allochthonous carbonate sediment input. However, complex limestone beds formed by amalgamation of successive carbonate deposits may represent condensed intervals of carbonate deposition. Marly intervals correspond to episodes of background sedimentation in generally low-energy environments. Marly intervals represent reduced or condensed deposits, developed in relatively low-energy water conditions, during prolonged episodes of sediment starvation. However, some marly intervals show evidence for episodic winnowing, taphonomic reworking and scouring.

The bed-scale limestone-marl alternation is primary in origin, although accentuated by diagenetic redistribution of carbonate (cf. Beaudoin et al. 1989). Lithologic differentiation between marly and limestone intervals resulted from alternating episodes of carbonate input and starvation. Simple limestone beds are expanded deposits, whereas marly intervals are condensed deposits. However, both lithologic phases may contain evidence for sedimentary and taphonomic reworking, associated with scours, that reflect low rate of sedimentation and stratigraphic condensation. The rate of sedimentation, or the degree of stratigraphic condensation, of a stratigraphic interval is calculated by dividing the thickness of sediment by the total time interval including the gaps. In contrast, the rate of sediment accumulation, or the degree of sedimentary condensation, of a stratigraphic interval can be estimated by dividing the thickness of sediment by the time interval of positive net sedimentation (Gómez \& FernándezLópez 1994, 2006; Fernández-López et al. 2002). Some complex limestone intervals may be more stratigraphically condensed than marly intervals (interval RB033-RB031, for example).
The proportion of marl vs. limestone intervals and elementary cycle thickness both decrease up-section. The three successive types of elementary cycles, from type 1 to type 3 , resulted from decreasing rates of sedimentation and sediment accumulation, respectively associated with increasing degrees of stratigraphic and sedimentary condensation, and increasing degrees of water turbulence and substrate stabilization (Fig. 12). The reduced rates of sediment accumulation, as well as the increasing sedimentary condensation and substrate stabilization by early diagenetic cementation, could have promoted an increasing seafloor colonization by sponges and a development of firm ground ichnocoenosis.

In Bas Auran area, decametre-scale sequences correspond to depositional cycles of several millions years, comparable to third-order sequences (Vail et al. 1991), on the basis of geochronological and geochronometric data (Gradstein \& Ogg 2004; Ogg 2004; Gradstein et al. 2005). At the upper Bajocian Parkinsoni Zone, Bomfordi Subzone, lowstand deposits may be represented by bundles of mudstone carbonates, in thick beds, intercalated with thin dark marly intervals (RB113-RB093, RA125-RA103). These aggrading carbonates correspond to sedimentation intervals in depositional environments having little hydrodynamic activity, dominated by soft grounds, during episodes of increasing accommodation. At the lower Bathonian, from the Parvum to Tenuiplicatus Subzone, a transgressive systems tract is represented by retrograding successions of fossiliferous mudstone to wackestone carbonates, in thin beds, showing evidence for increased stratigraphic, sedimentary and taphonomic condensation upwards (RB092-RB001, RA102-RA001). These retrograding successions represent sedimentation time-intervals in depositional environments having increasing hydrodynamic activity, dominated by soft to firm grounds, during episodes of decreasing rates of sedimentation and sediment accumulation associated with increasing accommodation. The hard grounds or corrosion surfaces on top of the 'Marno-calcaires à Cancellophycus' in Bas Auran area represent a time interval with no sedimentation and the deepest water conditions, associated with highest sediment reduction, during the early Bathonian. The high stand may consist of dark, organic-rich marls and shales, that lack sponge remains or reelaborated macrofossils and contain very scarce resedimented and crushed ammonoid shells, of the base of the 'Terres noires' Formation. These marly successions represent depositional environments with little hydrodynamic activity, dominated by soft grounds, during episodes of high rate of sedimentation, high rate of sediment accumulation and decreasing accommodation. 
Consequently, taphonomic analysis of the successive ammonoid fossil assemblages and taphofacies confirms the development of a deepening phase associated with sedimentary starvation, which characterizes the last episode within the deepening half-cycle of a third-order deepening/shallowing cycle, in the Bas Auran area of French Subalpine Basin during the early Bathonian. Moreover, this deepening phase corresponds to the maximum deepening of a second-order transgressive/regressive facies cycle ( $T / R$ 7, upper Aalenian - upper Bathonian, in Graciansky et al. 1993, 1998). In summary, the outcrop successions at Bas Auran show no obvious signs of non-sequence or discontinuity across the Bajocian/Bathonian boundary interval.

From a biochronostratigraphic point of view, over 52 successive ammonoid fossil assemblages belonging to three biohorizons of the Parvum Subzone have been recognized through $5 \mathrm{~m}$ of section (S.R. FernándezLópez, M.H. Henriques, Ch. Mangold \& G. Pavia, submitted). The Bomfordi Subzone attains a minimum thickness of $5 \mathrm{~m}$ and includes 42 successive ammonoid fossil assemblages. Consequently, this ammonoid succession on Bajocian/Bathonian passage shows a maximum value of biostratigraphic completeness and is one of the most complete in the world (FernándezLópez et al. 2006; Fernández-López in press).

\section{Conclusions}

The bed-scale limestone-marl alternation is primary in origin, although accentuated by diagenetic redistribution of carbonate. Lithologic differentiation between marly and limestone intervals resulted from alternating episodes of carbonate input and starvation. Both lithologic terms may contain evidence for sedimentary and taphonomic reworking, associated with scours, that reflects low rate of sedimentation and stratigraphic condensation during early Bathonian. Three successive types of elementary cycles, from type 1 to type 3 , resulted from increasing rates of stratigraphic condensation, sedimentary condensation and substrate stabilization. Taphonomic results confirm the development of a deepening phase associated with sedimentary starvation, which characterizes the last episode within a deepening half-cycle pertaining to third- and second-order cycles, in the Bas Auran area of French Subalpine Basin, during the early Bathonian. The maximum deepening of a secondorder transgressive/regressive facies cycle is at the end of the early Bathonian that corresponds to an extensional and deepening phase of the basin.

The three outcrop successions at Bas Auran show no obvious signs of non-sequence or discontinuity across the Bajocian/Bathonian boundary interval. There is no evidence for taphonomic condensation in the ammonoid fossil assemblages, except in level 002 (boundary between Recinctus and Tenuiplicatus subzones). On the Bajocian/Bathonian transition, the hemipelagic, bed-scale limestone-marl alternations show a maximum value of biostratigraphic completeness and the ammonoid succession is one of the most complete in the world.

Acknowledgements. - Thanks are due to the 'Reserve Naturelle Géologique de Haute-Provence' (Digne-les-Bains) for permission to work and sampling of the Bas Auran sections. Marco Pavia (Dipartimento di Scienze della Terra, University of Torino) found the specimen of Figure 6. I thank specially Giulio Pavia (Dipartimento di Scienze della Terra, University of Torino) for access to laboratory facilities, his help in the field and his comments on the geological setting of the Bajocian-Bathonian marly-calcareous succession in the Digne area. I am grateful to Carlton E. Brett (Department of Geology, University of Cincinnati), Charles Mangold (UFR des Sciences de la Terre et CNRS, Université Claude Bernard, Lyon) and Svend Stouge (editor-in-chief of Lethaia, Geological Museum, Copenhagen) for constructive suggestions of the manuscript. This work is a contribution to the Project CGL2004-0694/BTE (MEC-CSIC).

\section{References}

Beaudoin, B., El Khanchoufi, A., Monleau, C. \& Pinault, M. 1989: Transferts de matière dans les marno-calcaires alternants du Bajocien supérieur-Bathonien inférieur de la Sainte-Victoire. Comptes Rendus de l'Académie des Sciences de Paris 308, 641645.

Brett, C.E. 1995: Sequence stratigraphy, biostratigraphy, and taphonomy in shallow marine environments. Palaios 10, 597 616.

Brett, C.E. 1998: Sequence stratigraphy, paleoecology, and evolution: biotic clues and responses to sea-level fluctuations. Palaios 13, 241-262.

Bromley, R.G. 1996: Trace Fossils. 361 pp. Chapman and Hall, London.

Corbin, J.C., Person, A., Iatzoura, A., Ferre, B. \& Renard, M. 2000: Manganese in pelagic carbonates: indication of major tectonic events during the geodynamic evolution of a passive continental margin (the Jurassic European Margin of the Tethys-Ligurian Sea). Palaeogeography, Palaeoclimatology, Palaeoecology 156, 123-138.

Courville, P. \& Collin, P.Y. 2002: Taphonomic sequences - A new tool for sequence stratigraphy. Geology 30, 511-514.

Fernández-López, S. 1991: Taphonomic concepts for a theoretical biochronology. Revista Española de Paleontología 6, 37-49.

Fernández-López, S. 1995: Taphonomie et interprétation des paléoenvironnements. In Gayet, M. \& Courtinat, B. (eds): First European Palaeontological Congress, Lyon 1993. Geobios M.S. 18, 137-154.

Fernández-López, S. 1997a: Ammonites, clinos tafonómicos y ambientes sedimentarios. Revista Española de Paleontología $12,102-128$.

Fernández-López, S. 1997b: Ammonites, taphonomic cycles and stratigraphic cycles in carbonate epicontinental platforms. Cuadernos de Geología Ibérica 23, 95-136.

Fernández-López, S. 2000: Ammonite taphocycles in carbonate epicontinental platforms. In Hall, R.L. \& Smith, P.L. (eds): Advances in Jurassic Research 2000. GeoResearch Forum 6, 293 -300. Trans Tech Publications Ltd, Zürich.

Fernández-López, S. \& Meléndez, G. 1995: Taphonomic gradients in Middle Jurassic ammonites of the Iberian Range (Spain). In Gayet, M. \& Courtinat, B. (eds): First European Palaeontological 
Congress, Lyon 1993. Geobios, MS 18, 155-165. Université Claude-Bernard, Lyon I.

Fernández-López, S., Duarte, L.V. \& Henriques, M.H.P. 2000: Ammonites from lumpy limestones (Lower Pliensbachian, Portugal). Taphonomic analysis and palaeoenvironmental implications. Revista Sociedad Geológica de España 13, 3-15.

Fernández-López, S., Henriques, M.H., Linares, A., Sandoval, J. \& Ureta, M.S. 1999: Aalenian Tmetoceras (Ammonoidea) from Iberia: taphonomy and palaeobiogeography. In Olóriz, F \& Rodríguez Tovar, F.J. (eds): Cephalopods-Present and Past, 395-417. Kluwer Academic/Plenum Publishers, New York.

Fernández-López, S.R. 2005: Distinction between abrasion furrows and infill channels in ammonite internal moulds. In Martinell, J., Domènech, R. \& de Gibert, J.M. (eds): 2nd International Meeting Taphos 05/4a Reunión de Tafonomía y Fosilización, 109-110. Universitat de Barcelona, Spain.

Fernández-López, S.R. in press: Candidate sections for GSSP of the base of Bathonian Stage (Middle Jurassic). Volumina Jurassica.

Fernández-López, S.R. \& Gómez, G. 2004: The Middle Jurassic eastern margin of the Iberian platform system (eastern Spain). Palaeogeography and biodispersal routes of ammonoids. Rivista Italiana di Paleontologia e Stratigrafia 110, 151-162.

Fernández-López, S.R. \& Meléndez, G. 2004a: Fossilization of ammonites and sedimentary events in deep environments of carbonate platform (highest Middle to lowest Upper Oxfordian, Iberian Range, Spain). Rivista Italiana di Paleontologia $e$ Stratigrafia 110, 219-230.

Fernández-López, S.R. \& Meléndez, G. 2004b: Taphonomic features of ammonite associations developed in deep carbonate platform environments (Oxfordian, Iberian Range, Spain). In Pena dos Reis, R., Callapez, P. \& Dinis, P. (eds): 23rd IAS Meeting, Abstracts Book 113. Impresa de Coimbra, Portugal.

Fernández-López, S.R., Henriques, M.H.P. \& Duarte, L.V. 2002: Taphonomy of ammonite condensed associations. Jurassic examples from carbonate platforms of Iberia. Abhandlungen der Geologischen Bundesanstalt 57, 423-430.

Fernández-López, S.R., Henriques, M.H. \& Mangold, Ch. 2006: Ammonite succession at the Bajocian/Bathonian boundary in the Cabo Mondego region (Portugal). Lethaia 39, 253-264.

Ferry, S. 1991: Une alternative au modèle de stratigraphie séquentielle d'Exxon: la modulation tectono-climatique des cycles orbitaux. Géologie Alpine, HS 18, 47-99.

Ferry, S. \& Dromart, G. 1991: Facies variability of transgressive and regressive systems of gravity deposits in deep-water carbonates (Mesozoic, French Alps). The American Association of Petroleum Geologists Bulletin 75, 572-573.

Ferry, S. \& Mangold, Ch. 1995: Faciès de dépôt et stratigraphie séquentielle des calcaires bajociens du Jura méridional. Documents des Laboratoires de Géologie Lyon 133, 1-96.

Ferry, S. \& Mouterde, R. 1989: Stop 18. In Ferry, S. \& Rubino, J.L. (eds): Mesozoic Eustasy or Western Tethyan Margins. PostMeeting Field Trip in the Vocontian Trough. 2ème Congrès Français de Sédimentologie, 110-111. Université ClaudeBernard, Lyon I.

Ferry, S., Atrops, F. \& Mouterde, R. 1991: Case studies of parasequences-steepped ammonite turnovers in transgressive systems tracts (Jurassic, Vocontian Trough, France). The American Association of Petroleum Geologists Bulletin 75, 573.

Ferry, S., Mouterde, R., Atrops, F., Dromart, G., Chevallier, T., Rubino, J.-L. \& Crumière, J.P. 1989: A revision of the Mesozoic sea level chart of Haq et al. (1987) from the carbonate wedge of the French Alpine margin. 2ème Congrès Français de Sédimentologie, 33-34. Université Claude-Bernard, Lyon I.

Fürsich, F.T. \& Oschmann, W. 1993: Shell beds as tools in basin analysis: the Jurassic of Kachchh, western India. Journal of the Geological Society, London 150, 169-185.

Gómez, J.J. \& Fernández-López, S. 1994: Condensation processes in shallow platforms. Sedimentary Geology 92, 147-159.

Gómez, J.J. \& Fernández-López, S. 2006: The Iberian Middle Jurassic carbonate-platform system: synthesis of the palaeogeographic elements of its eastern margin (Spain). Palaeogeography, Palaeoclimatology, Palaeoecology 236, 190-205.
Graciansky, P.-C. De, Durozoy, G. \& Gigot, P. 1982: Carte Géologique de la France à 1:50000, Digne. 75 pp. BRGM, Paris. Graciansky, P.-C. De, Dardeau, G., Dumont, T., Jacquin, T., Marchand, D., Mouterde, R. \& Vail, P.R. 1993: Depositional sequence cycles, transgressive-regressive facies cycles, and extensional tectonics; example from the southern subalpine Jurassic basin, France. Bulletin de la Société Géologique de France 164, 709-718.

Graciansky, P.-C. De, Dardeau, G., Bodeur, Y., Elmi, S., Fortwengler, D., Jacquin, T., Marchand, D. \& Thierry, J. 1998: Les Terres Noires du Sud-Est de la France (Jurassique moyen et supérieur): interprétation en termes de stratigraphie séquentielle. Bulletin $d u$ Centre de Recherches Elf Exploration-Production 22, 3566.

Gradstein, F.M. \& Ogg, J.G. 2004: Geologic Time Scale 2004 why, how and where next! Lethaia 37, 175-181.

Gradstein, F.M., Ogg, J.G. \& Smith, A.G. (eds) 2005: A Geologic Time Scale 2004. 589 pp. Cambridge University Press, Cambridge, UK.

Hardenbol, J., Thierry, J., Farley, M.B., Jacquin, T., Graciansky, P-C. De \& Vail, P.R. 1998: Mesozoic and Cenozoic sequence chronostratigraphic framework of European Basins. In Graciansky, P.C. De, Hardenbol, J., Jacquin, T. \& Vail, P.R. (eds): Mesozoic and Cenozoic Sequence Stratigraphy of European Basins, 3-14. SEPM (Society for Sedimentary Geology) Special Publication, No. 60, Tulsa, Oklahoma.

Hudson, J.D. \& Martill, D.M. 1991: The Lower Oxford Clay: production and preservation of organic matter in the Callovian (Jurassic) of central England. In Tyson, R.V. \& Pearson, T.H. (eds): Modern and Ancient Continental Shelf Anoxia, 363-379. Geological Society Special Publication, No. 58, London.

Innocenti, M., Mangold, Ch., Pavia, G. \& Torrens, H.S. 1988: A proposal for the formal ratification of the basal boundary stratotype of the Bathonian Stage based on a Bas Auran section (S.E. France). In Rocha, R.B. \& Soares, A.F. (eds): 2nd International Symposium on Jurassic Stratigraphy, 333-346. Centro de Estratigrafia e Paleobiologia, Universidade Nova de Lisboa, Lisbon, Portugal.

Jacquin, T., Dardeau, G., Durlet, C., Graciansky, P.C. De \& Hantzpergue, P. 1998: The North Sea Cycle: an overview of 2nd-order transgressive/regressive facies cycles in Western Europe. In Graciansky, P.C. De, Hardenbol, J., Jacquin, T. \& Vail, P.R. (eds): Mesozoic and Cenozoic Sequence Stratigraphy of European Basins, 445-466. SEPM (Society for Sedimentary Geology) Special Publication, No. 60, Tulsa, Oklahoma.

Jenkyns, H., Jones, C., Gröcke, D., Hesselbo, S. \& Parkinson, N. 2002: Chemostratigraphy of the Jurassic System: applications, limitations and implications for palaeoceanography. Journal of the Geological Society, London 159, 351-378.

Lenoble, A. \& Bertran, P. 2004: Fabric of Palaeolithic levels: methods and formation processes. Journal of Archaeological Science 31, 457-469.

Maeda, H. \& Seilacher, A. 1996: Ammonoid taphonomy. In Landman, N.H., Tanabe, K. \& Davis, R.A. (eds): Ammonoid Paleobiology, 543-578. Plenum Press, New York.

Mouterde, R., Sadki, D., Chevalier, T. \& Ferry, S. 1989: A revision of the Mesozoic sea level chart of Haq et al. (1987) from the carbonate wedge of the French Alpine margin. 2ème Congrès français de Sédimentologie, 48-50. Université Claude-Bernard, Lyon I.

Ogg, J.G. 2004: Status of divisions of the international geologic time scale. Lethaia 37, 183-199.

Olivero, D. 1994: La trace fossile Zoophycos du Jurassique du Sud-Est de la France. Signification paleoenvironnementale. Documents des Laboratoires de Géologie Lyon 129, 1-329.

Olivero, D. 2003: Early Jurassic to Late Cretaceous evolution of Zoophycos in the French Subalpine Basin (southeastern France). Palaeogeography, Palaeoclimatology, Palaeoecology 192, 59-78.

Olivero, D. \& Atrops, F. 1996: Les séries à Zoophycos du BathonienCallovien de l'Arc de Castellane (SE de la France) dans la zone de transition plate-forme/basin: stratigraphie et paléotectonique. Comptes Rendus de l'Académie des Sciences de Paris 323, 81-88. 
Olivero, D. \& Gaillard, C. 1996: Paleocology of Jurassic Zoophycos from South-eastern France. Ichnos 4, 249-260.

Olivero, D., Mangold, Ch. \& Pavia, G. 1997: La formation des Calcaires à Zoophycos du Verdon (Bathonien inférieur à Callovien moyen) des environs de Castellane (Alpes-deHaute-Provence, France): biochronologie et lacunes. Comptes Rendus de l'Académie des Sciences de Paris 324, 33-40.

Pavia, G. 1973: Ammoniti del Baiociano superiore di Digne (Francia SE, Dip. Basses-Alpes). Bollettino della Società Paleontologica Italiana, 10 (1971), 75-142.

Reboulet, S., Giraud, F. \& Proux, O. 2005: Ammonoid abundance variations related to changes in trophic conditions across the oceanic anoxic event 1d (Latest Albian, SE France). Palaios 20, 121-141.

Reboulet, S., Mattioli, E., Pittet, B., Baudin, F., Olivero, D. \& Proux, O. 2003: Ammonoid and nannoplankton abundance in Valanginian (early Cretaceous) limestone-marl successions from the southeast France Basin: carbonate dilution or productivity? Palaeogeography, Palaeoclimatology, Palaeoecology 201, 113-139.

Seilacher, A., Andalib, F., Dietl, G. \& Gocht, H. 1976: Preservational history of compressed Jurassic ammonites from southern
Germany. Neues Jahrbuch für Geologie und Paläontologie, Abhandlungen 152, 307-356.

Sturani, C. 1967: Ammonites and stratigraphy of the Bathonian in the Digne-Barrême area (South Eastern France). Bolletino Della Societa Paleontologica Italiana 5 (1966), 3-57.

Tintant, H. 1984: Autochtonie ou allochtonie chez les Céphalopodes. Mémoires de Géologie Université Dijon 7 (1982), 257-271.

Torrens, H. 1987: Ammonites and stratigraphy of the Bathonian rocks in the Digne-Barrême area (South-Eastern France, Dept. Alpes de Haute Provence). Bolletino della Societa Paleontologica Italiana 26, 93-108.

Vail, P.R., Audemard, F., Bowman, S.A., Eisner, P.N. \& PérezCruz, C. 1991: The stratigraphic signatures of tectonics, eustasy and sedimentology - an overview. In Einsele, G., Ricken, W. \& Seilacher, A. (eds): Cycles and Event in Stratigraphy, 617659. Springer, Berlin, Germany.

Zany, D., Atrops, F., Marchand, D. \& Thierry, J. 1990: Nouvelles données biostratigraphiques sur les series du Bathonien et du Callovien des environs de Digne (Alpes-de-Haute-Provence). Géologie Méditerranéenne 17, 39-53. 